世界の皮膚科学者（118）

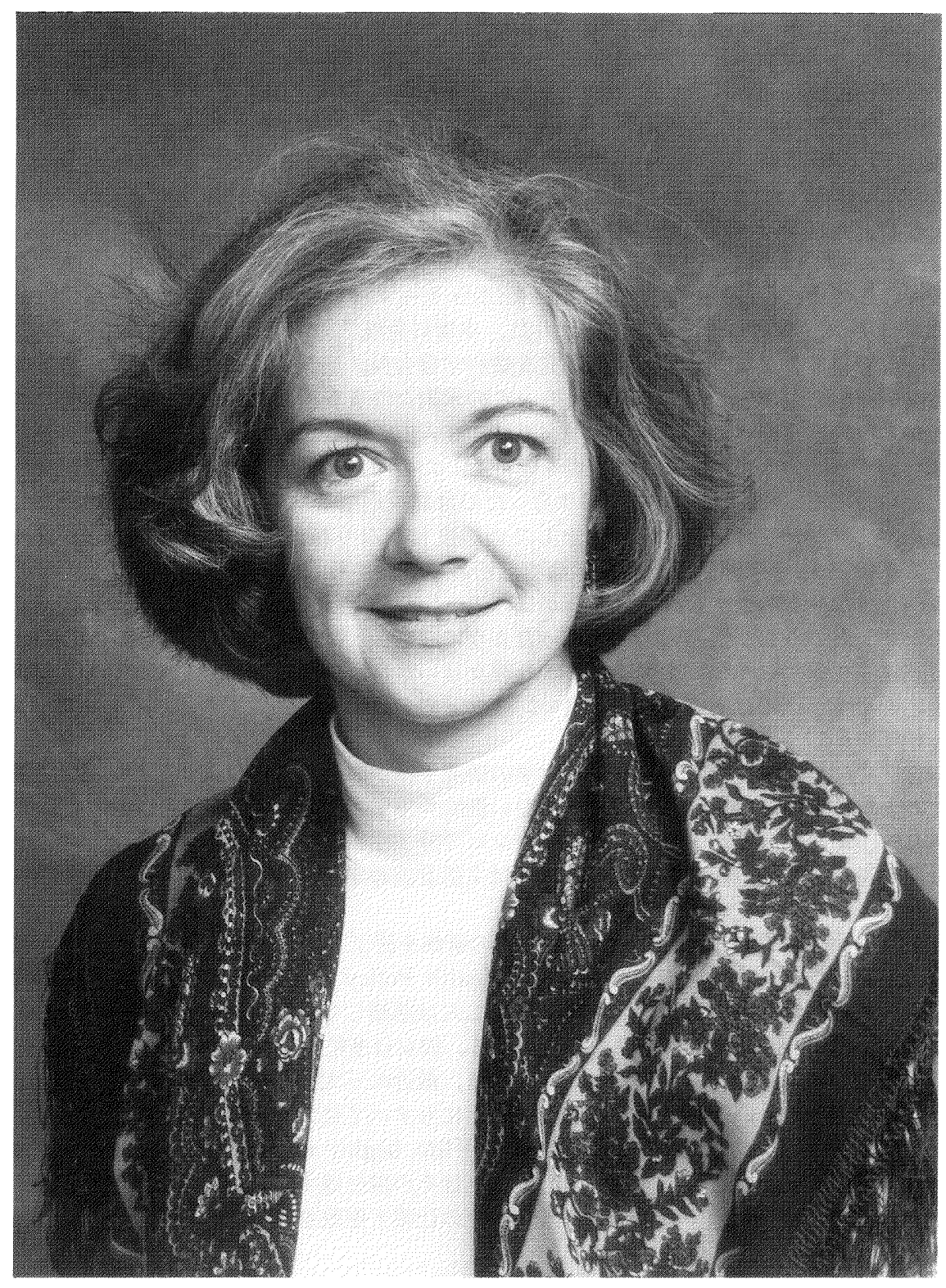

Dr. M. Joyce Rico 


\section{Dr. M. Joyce Rico}

日本では勿論，欧米でも医師と妻と母親の三役をこなすことは容易なことではない。 本誌編集長の堀 嘉昭教授のお許しを願って, 今回は水疱症の研究に打ち込んでいる, 米国デューク大学の若手助教授 M. ジョイス・リコ博士を御紹介させて頂くことにした。 リコ博士はフロリダ州立大学, フロリダ大学薬学部を経て, 同大学医学部を 1981 年に 卒業, マイアミの Mt. Sinai Medical Center て 1 年の内科, そしてマイアミ大学医学 部で 3 年の皮虐科レジデントとして研修を行った。その後マイアミ大学微生物・免疫学 教室にて J. W. Streilein 教授の下で 1 年間免疫学の研究を行うと共に同大学皮席科講師 を務め, 1986 年からデューク大学皮膚科へ移り, 皮膚科専門医として働きながら, ラッセル・ホール準教授の下で皮店科允疫学の研究を続け 1988 年からはデューク大学助 教授として自己兔疫性水疱症の研究をメイン・テーマとしている。彼女から送られた C. V.によれば，皮虐科専門医の資格と共に，皮㯰科免疫学の特別資格をも取得している。 米国皮膚科アカデミー会員, 米国研究皮鬳科学会会員, 皮膚科財団会員に加え, 米国女 性皮㬝科学会理事として活躍中である。この米国女性皮暍科学会という組織は結成され てからそれほど経っていないが, 現在では 400 人位の会員があるとのことで, その活動 は「闘う」というょりも女医の立場を「守る」ためであるという。

といっても，そもそも彼女と知り合ったのは類天疱瘡患者のリンパ球の cell line 化 をめぐる「刘決」であり, 研究者としての態度はかなり積極的で確固たるものがあっ た。私は 1989 年米国研究皮痛科学会で, 初めて会話することになったが, 学会場で視 線が合うなりその大きな朣は, 明らかに“表へ出ろ!!”と言っていた。“何故,できた のか?”というのが最初の会話であったように思う(研究内容の詳細はJ Invest Dermatol 90:567A, 602A，1988.)。しかし彼女はいかにも理知的でチャーミングであり, 反応も早く小柄ではあるが気風が良い。彼女との会話は常に生き生きとして気持ちが良 く相手を楽しくさせる。

自己免疫性水疮症の研究は分子生物学の研究手技が導入されて以来, 新しい展開を迎 えたといえる。彼女はこの分野で数少ない細胞免疫学者で, リンパ球の動向に注目して おり, 上司のラッセル・ホール博士とコンピで分子生物学の成果をも導入したユニーク な研究を続けている。私達のグループとは文部省国際学術研究を通しての共同研究者の ひとりである。

彼女の夫, W. Paul Kory 博士は病理学の研修空終了し, 予防医学の資格を取得して いるが, 目下ノースカロライナ大学で「Health Policy and Administration」の PhD の取得を目前にしているとのことである。二人は結婚して 13 年になり，8歳の Sean, 3 歳の Elizabeth の二人の子供(養子)がある。彼女は多忙な日常の余㗇に読書や裁縫に 時間を費やす他, 旅行が大好きで, とりわけ, 最近の三大陸研究皮膚科学会で来日の折 には，京都の町も庭園も日本料理もカラオケにもすべてに大満足したと言う。

東洋には「四十にして惑わず」，欧米では「life begins at forty」と言われるように 「youngest(?) woman staff」の彼女もいずれはその域に達するものと思われるが，良い 上司, 同僚, 家族に恵まれ, 今後も大学病院の仕事と家庭を両立させつつ, 一層の活躍 をしてもらいたいものである。 